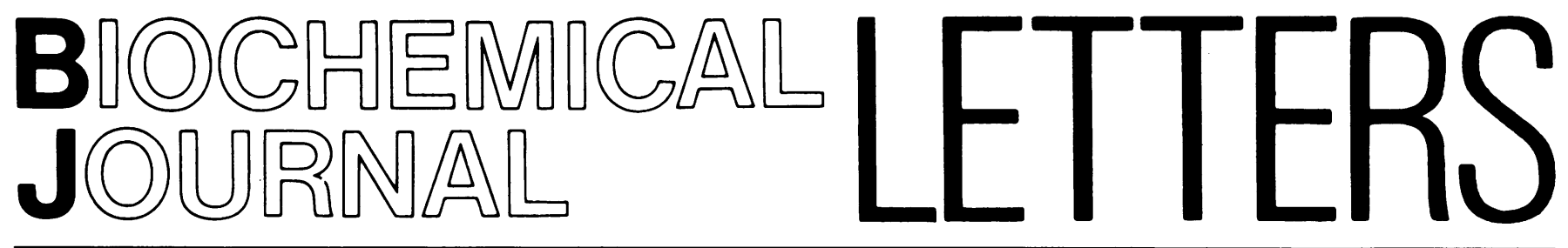

\section{ATP and the binding of $\left[{ }^{3} \mathrm{H}\right]$ inositol $1,4,5-$ trisphosphate to its receptor}

There are now several reports of the specific reversible binding of inositol 1,4,5-trisphosphate $\left(\operatorname{Ins} P_{3}\right)$ to permeabilized cells or particulate preparations of several tissues $[1,2,3,4]$. In some [1,2,3], though not all [4], of these preparations, equilibrium dissociation constants $\left(K_{\mathrm{D}}\right)$ for Ins $P_{3}$ binding have been reported to be in the low nanomolar range, whereas effective concentrations to release $\mathrm{Ca}^{2+}$ from intracellular stores, often from the same preparation, are one to two orders of magnitude greater. This could suggest that the binding site and sites associated with $\mathrm{Ca}^{2+}$ release are different or that the conditions of the assays substantially alter the binding affinity of Ins $P_{3}$.

In this context we have reported that ATP, which is generally present in millimolar concentrations in $\mathrm{Ca}^{2+}$ release assays, inhibited the specific binding of $\left[{ }^{3} \mathrm{H}\right]$ Ins$(1,4,5) P_{3}$ to a particulate site prepared from rat cerebellum [ $\mathrm{IC}_{50}$ (concentration producing $50 \%$ inhibition) $51 \mu \mathrm{M}$ ] [5]. Since these sites have been characterized for stereoand positional specificity and possess qualitative properties in this respect very similar to those associated with $\mathrm{Ca}^{2+}$ release [6], we considered that the difference in apparent affinity between the systems could relate to the presence of ATP in the $\mathrm{Ca}^{2+}$ assays. Inhibitory effects of ATP on Ins $P_{3}$ binding have been confirmed in other systems $[1,3]$, but a recent letter to this journal [7] suggested that this inhibitory effect was not related to ATP itself but to some impurity in certain preparations. In particular, it was reported that ATP from Pharmacia (type 27-1006-0) is inactive on Ins $P_{3}$ binding to pituitary microsomes.

Using our cerebellar membrane preparation, which has been carefully evaluated for stereo- and positional specificity [5], we have failed to reproduce these results. For example, in our hands ATP (Sigma A2383) and ATP (Pharmacia, type 27-1006-0) produce superimposible inhibition curves against $15 \mathrm{nM}-\left[{ }^{3} \mathrm{H}\right] \mathrm{Ins}(1,4,5) P_{3}$ with $\mathrm{IC}_{50}$ values of $7.9( \pm 0.67) \times 10^{-4} \mathrm{M}$ and $7.6( \pm 0.80) \times 10^{-4} \mathrm{M}$ respectively. Furthermore, ATP preparations from several other commercial sources were identical in this respect. AMP and ADP possessed $\mathrm{IC}_{50}$ values in excess of $5 \times 10^{-3} \mathrm{M}$.

It is not clear why these data differ from those in pituitary microsomes, or indeed if the inhibition by ATP is competitive; however, it still remains possible that the discrepancy between the effectiveness of $\operatorname{Ins}(1,4,5) P_{3}$ in releasing $\mathrm{Ca}^{2+}$ and its affinity for receptor binding relates to the presence of greater-than-millimolar concentrations of ATP in many of the former systems. In this context it should be noted that a very recent report [8] has shown that, in the absence of ATP, $\operatorname{Ins}(1,4,5) P_{3}$ can release $\mathrm{Ca}^{2+}$ from intracellular stores of permeabilized rat basophilic leukaemic cells in a highly co-operative manner in the 4-40 $\mathrm{nM}$ concentration range.

\section{Alan L. WILLCOCKS and Stefan R. NAHORSKI}

Department of Pharmacology and Therapeutics, University of Leicester, P.O. Box 138, Medical Sciences Building, University Road, Leicester LE1 9HN, U.K.

1. Guillemette, G., Balla, T., Baukal, A. J. \& Catt, K. J. (1987) Proc. Natl. Acad. Sci. U.S.A. 84, 8195-8199

2. Spat, A., Bradford, P. G., McKinney, J. S., Rubin, R. P. \& Putney, J. W. (1986) Nature (London) 319, 514-516

3. Guillemette, G., Balla, T., Baukal, A. J. \& Catt, K. J. (1988) J. Biol. Chem. 263, 4541-4548

4. Worley, P. F., Baraban, J. M., Colvin, J. S. \& Snyder, S. H. (1987) Nature (London) 325, 159-161

5. Willcocks, A. L., Cooke, A. M., Potter, B. V. L. \& Nahorski, S. R. (1987) Biochem. Biophys. Res. Commun. 146, 1071-1078

6. Strupish, J., Cooke, A. M., Potter, B. V. L., Gigg, R. \& Nahorski, S. R. (1988) Biochem. J. 253, 901-905

7. Eberhardt, I., Kiesel, L. \& Spat, A. (1988) Biochem. J. 250, 311

8. Meyer, T., Holowka, D. \& Stryer, L. (1988) Science 240, 653-656

Received 28 July 1988 